\title{
Allergen-induced late-phase airways obstruction in the pig: mediator release and eosinophil recruitment
}

\author{
C. Fornhem*, M. Kumlin**, J.M. Lundberg*, K. Alving*
}

\begin{abstract}
Allergen-induced late-phase airways obstruction in the pig: mediator release and eosinophil recruitment. C. Fornhem, M. Kumlin, J.M. Lundberg, K. Alving. @ERS Journals Ltd 1995.

ABSTRACT: The aim of this study was to develop a novel model for studies of mediator mechanisms involved in the late asthmatic reaction in the lower airways, by using the sensitized pig. The release of histamine and cysteinyl-containing leukotrienes (cys-LTs), as well as the levels of inflammatory cells in blood and bronchoalveolar lavage fluid, were determined and their relationship to plasma cortisol levels and pulmonary airways obstruction was noted.

Specific-pathogen free pigs were actively sensitized with Ascaris suum allergen, and one group of animals was treated with a cortisol-synthesis inhibitor (metyrapone) by constant intravenous infusion. Ascaris suum allergen was nebulized into the lower airways and total lung resistance, blood leucocyte count and urinary levels of methylhistamine and leukotriene $E_{4}\left(\operatorname{LTE}_{4}\right)$ were followed for $8 \mathrm{~h}$, whereafter bronchoalveolar lavage was performed for analysis of leucocytes.

An increase in urinary methylhistamine and $\mathrm{LTE}_{4}$ was seen during the acute allergic reaction in both groups of pigs. Metyrapone treatment prolonged the acute release of histamine, and this was seen together with a prolonged acute bronchoconstrictor response. In metyrapone-treated pigs, a continuous release over 8 h was seen for cys-LTs, but not for histamine. A late blood eosinophilia was also seen in metyrapone-treated animals, starting 4-6 h after allergen challenge. Late cys-LT release and eosinophilia were absent in non-metyrapone-treated animals.

These results suggest that allergen-induced late release of cys-LTs as well as blood eosinophilia occur simultaneously with late-phase airways obstruction in the pig, and that all these reactions are prevented by high levels of endogenous cortisol. Eur Respir J., 1995, 8, 1100-1109.
\end{abstract}

The association between increased numbers of eosinophils in the lung and human bronchial asthma was shown by ELLIS [1] in 1908, and is today well-established. However, the exact mechanism of action of eosinophils and the relevance of the eosinophilia sometimes seen in asthma are not yet fully understood. We wanted to establish a large animal model for studies of the initiation of allergic inflammation in the airways, and the pig has been found to be suitable for such studies [2-4].

The mast cell plays a pivotal role in the acute asthmatic response, in that it releases mediators, such as histamine and cysteinyl-containing leukotrienes (cys-LTs) [5]. Measurements of free levels of histamine and cysLTs in plasma may be difficult, due to uncontrolled release from blood leucocytes. Therefore, the relatively stable urinary end-metabolites methylhistamine [6] and leukotriene $\mathrm{E}_{4}\left(\mathrm{LTE}_{4}\right)$ [7], respectively, were measured in this study. The possible involvement of cys-LTs in the late-phase reaction has been studied in animal models [8], and in humans [7, 9]. However, with the data available at present, there is no clear evidence whether or not a second cys-LT release takes place in association with late-phase bronchoconstriction. Another possible source of cys-LTs, besides mast cells, is eosinophils that may release large amounts of leukotriene $\mathrm{C}_{4}\left(\mathrm{LTC}_{4}\right)$ [10]. Cys-LTs have also been shown to recruit eosinophils when given to asthmatics [11], and to induce latephase bronchoconstrictor reactions in sheep [12]. Since the activity of eosinophils is reduced by glucocorticoids [13], it was of interest to evaluate the effects of endogenous cortisol on eosinophil recruitment as well as mediator release. In the present study, this was done by pretreatment of the animals with metyrapone, a cortisol-synthesis inhibitor [14].

This study, using actively-sensitized pigs, was initiated in order to obtain a novel model for studies of mechanisms involved in the late asthmatic reaction. Allergen challenge in the lower airways was performed in anaesthetized and mechanically-ventilated pigs. Blood leucocyte numbers and levels of urinary methylhistamine and $\mathrm{LTE}_{4}$ were then followed for $8 \mathrm{~h}$, whereafter, a bronchoalveolar lavage (BAL) was performed and cells were counted.

\section{Methods}

The experiments were approved by the local Ethics Committee for animal research. 


\section{Surgical preparation}

Twenty three specific pathogen-free pigs of either sex were used in the study. Fifteen of them were sensitized with subcutaneous injections of 0.6-1.0 mg Ascaris suum (A. suum) allergen (Pharmacia Diagnostics, Uppsala, Sweden) as described previously [2]. Eight pigs served as controls and were not sensitized. About one week after the third injection (at a body weight of $25-30 \mathrm{~kg}$ ), the pigs were fasted overnight and premedicated with ketamine hydrochloride (Parke-Davis, Barcelona, Spain; $20 \mathrm{mg} \cdot \mathrm{kg}^{-1}$ i.m.). Anaesthesia was induced by sodium pentobarbitone (Apoteksbolaget, Umeå, Sweden; 12 $\mathrm{mg} \cdot \mathrm{kg}^{-1}$ i.v.) introduced into an ear vein. Blood samples for analysis of morning basal count of blood leucocytes were successfully drawn in 14 pigs from this vein. The adequacy of anaesthesia was tested by pinching the interdigital skin. After tracheotomy, the pigs were intubated and ventilated with a mixture of oxygen and air using a Servo ventilator (900; Siemens-Elema, Sweden). Muscle relaxation was achieved with pancuronium bromide (Organon, Oss, The Netherlands; $0.2 \mathrm{mg} \cdot \mathrm{kg}^{-1} i . v$.). Anaesthesia was maintained by continuous i.v. infusion of pentobarbitone (7-9 $\left.\mathrm{mg} \cdot \mathrm{kg}^{-1} \cdot \mathrm{h}^{-1}\right)$ and pancuronium $\left(0.6 \mathrm{mg} \cdot \mathrm{kg}^{-1} \cdot \mathrm{h}^{-1}\right)$ through a catheter in one femoral vein. Ringer solution with $0.5 \%$ glucose $\left(250 \mathrm{~mL} \cdot \mathrm{h}^{-1}\right)$ was given through the same catheter.

A femoral artery was cannulated for monitoring mean arterial blood pressure and heart rate, in order to adjust the level of anaesthesia. All blood samples were drawn via a catheter positioned in a brachial artery. Heparin was given through each of the catheters to a total of 4,000 IU before the start of the experiment. Arterial blood gas partial pressures and $\mathrm{pH}$ were regularly monitored using an automatic blood gas analyser (IL 1302, Metric AB, Solna, Sweden). Body temperature was maintained at $38-39^{\circ} \mathrm{C}$ with a heating pad connected to a thermostat. For urine collection, the ureter on the left side was dissected free and a catheter was inserted. The respiratory pressure was measured by connecting an outlet of the extratracheal tube to a Statham PM 131 TC pressure transducer and this value was used as a measure of transrespiratory pressure, since intratracheal pressure was equal to atmospheric pressure because of a thoracotomy. Airflow was measured with a heated Fleisch No. 1 pneumotachograph connected to a Statham PM 15 E pressure transducer. Airflow and transpulmonary pressure signals were sent to an AP 200 Pulmonary Computer (ConMeTech AB, Uppsala, Sweden) for calculation of total lung resistance $(R \mathrm{~L})$ as described earlier [4].

\section{Experimental procedures}

A skin test was performed using a standardized extract of A. suum to verify the sensitivity to the allergen. Only pigs responding to a tenfold or more dilution of the A. suum extract were included in the study.

Eight of the sensitized pigs and five of the nonsensitized were given the cortisol-synthesis inhibitor metyrapone (Sigma, St. Louis, MO, USA) as a bolus dose of $25 \mathrm{mg} \cdot \mathrm{kg}^{-1} 2 \mathrm{~h}$ before allergen challenge, followed by a continuous infusion i.v. $\left(10 \mathrm{mg} \cdot \mathrm{kg}^{-1} \cdot \mathrm{h}^{-1}\right)$. Following a stabilization period of $1.5 \mathrm{~h}$ after the surgical preparation, the allergen aerosol challenge was performed. The allergen consisted of an extract of $A$. suum, with a protein concentration of $7 \mathrm{mg} \cdot \mathrm{mL}^{-1}$ in a volume of $2.0 \mathrm{~mL}$ of saline. The aerosol was generated using an ultrasonic nebulizer (NB 108, Engström Medical, Stockholm, Sweden) and was delivered over 5 min via the tracheal tube to the lower airways. Arterial blood was drawn for cell analysis $15 \mathrm{~min}$ before and $15 \mathrm{~min}, 1,2,4,6$ and 8 $\mathrm{h}$ after the allergen challenge. Urine was collected in one hour fractions, starting one hour prior to the allergen challenge, for determination of methylhistamine, $\mathrm{LTE}_{4}$ and creatinine. At the end of the observation period a fibreoptic bronchoscope for paediatric use (Machida No. 11742, MUAB, Bromma, Sweden) was inserted in a segment of the right middle lobe, and BAL was performed with two $50 \mathrm{~mL}$ aliquots of $37^{\circ} \mathrm{C}$ saline. At the end of the experiments, the animals were killed with an overdose of pentobarbitone.

\section{Sample collection and processing}

Blood was gently mixed with ethylenediamine tetraacetic acid (EDTA) to a final concentration of $10 \mathrm{mM}$. Total blood cell count was performed in a Bürker chamber after staining with gentian violet (Merck, Darmstadt, Germany) in $6.25 \%$ acetic acid (Türk's solution), and at least 100 cells were counted. Differential blood leucocyte counts were performed on glass slides, after fixation of cell smears in methanol for $5 \mathrm{~min}$ and staining in May-Grünwald (Merck) for 5 min and, subsequently, with Giemsa (Merck) for 15 min; whereafter, 200 cells were counted. Urine was collected on ice and samples were centrifuged for $10 \mathrm{~min}$ at $4{ }^{\circ} \mathrm{C}$ and $680 \times \mathrm{g}$ and stored at $-70^{\circ} \mathrm{C}$ until analysed. The fluid recovered from the two BAL samples was pooled and centrifuged for 10 min at $4^{\circ} \mathrm{C}$ and $170 \times \mathrm{g}$. The pellet was resuspended in $5.0 \mathrm{ml}$ of saline and total cell number counted. The cells were diluted in saline to a concentration of $2.0 \times 10^{5}$ cells $\cdot \mathrm{mL}^{-1}$ and $200 \mu \mathrm{L}$ aliquots were prepared on glass slides using a cytocentrifuge (Cytospin 2, Shandon, Southern Products Ltd, Cheshire, UK) spinning at 500 r.p.m. for $5 \mathrm{~min}$. After fixation in methanol the cells were stained with May-Grünwald Giemsa (see above). Differential cell counts were performed by counting 400 leucocytes.

Plasma cortisol was determined using a radio-immunoassay (Orion Diagnostica AB, Trosa, Sweden), with a detection limit of 3-5 nM. Methylhistamine was determined using a radio-immunoassay (Pharmacia Diagnostics, Uppsala, Sweden) after dilution of samples 500 times.

In order to verify the identity of the immunoreactive $\mathrm{LTE}_{4}$, urine samples collected 0-2 $\mathrm{h}$ after allergen provocation were pooled and purified by solid phase extraction and reversed phase high performance liquid chromatography (RP-HPLC), as described previously [15]. Briefly, methanol eluates from extraction columns were evaporated and the residue redissolved in HPLCmobile phase (72:28:0.1; methanol:water:acetic acid, $\mathrm{pH}$ 
adjusted to 4.2 with $\mathrm{NH}_{4} \mathrm{OH}$ in the water phase) and injected onto a HPLC-column (Nucleosil C18, 4.5×200 $\mathrm{mm}, 5 \mu \mathrm{m}$ particle size, Macherey-Nagel, Düren, Germany) at a flow rate of $0.8 \mathrm{~mL} \cdot \mathrm{min}^{-1}$. HPLC-fractions $(0.8 \mathrm{~mL})$ were further analysed for content of $\mathrm{LTE}_{4}$-like immunoreactivity. Losses during purification were estimated by the recovery of ${ }^{3} \mathrm{H}_{-} \mathrm{LTE}_{4}\left(10,000 \mathrm{dpm} ; 150 \mathrm{Ci} \cdot \mathrm{mmol}^{-1}\right.$, NEN, Boston, MA, USA) in aliquots of samples purified in parallel.

Immunoreactive $\mathrm{LTE}_{4}$ equivalents were determined with radio-immunoassay, using ${ }^{3} \mathrm{H}-\mathrm{LTE}_{4}$ as a tracer and a monoclonal leukotriene $\mathrm{D}_{4}\left(\mathrm{LTD}_{4}\right)$-antibody with crossreactivities for $\mathrm{LTC}_{4}$ and $\mathrm{LTE}_{4}$ around $50 \%$ (Advanced Magnetics Inc., Cambridge, MA, USA). The standard curve was set up with synthetic $\mathrm{LTE}_{4}$ and the detection limit was around $20 \mathrm{nmol}$. All reagents were incubated at $4{ }^{\circ} \mathrm{C}$ overnight. The antigen-antibody complexes formed were precipitated with polyethylene glycol, followed by centrifugation and liquid scintillation counting of free radiolabelled ligand in the supernatant.

Creatinine was determined by standard colorometric assay using the alkaline picrate method (Sigma Diagnostics, St. Louis, MO, USA).

\section{Calculations and statistics}

The amount of methylhistamine was expressed as mmol methylhistamine per mol creatinine, to compensate for changes in kidney function. The amount of $\mathrm{LTE}_{4}$ was expressed as $\mu \mathrm{mol}$ of $\mathrm{LTE}_{4}$ per mol creatinine. $\mathrm{LTE}_{4}$ concentrations in sensitized pigs are presented as increases compared to levels in nonsensitized animals.

The total responses were calculated as area under the curve (AUC) for the increase in $R_{\mathrm{L}}(\% \cdot \mathrm{h})$, leucocyte count $\left(10^{9} \cdot \mathrm{L}^{-1} \cdot \mathrm{h}\right)$ or mediator release $(\mathrm{mol} \cdot \mathrm{mol}$ creatinine $\left.^{-1} \cdot \mathrm{h}\right)$. Correlation analysis of these total responses was performed in sensitized, metyrapone-treated pigs. To make it possible to distinguish between direct bronchoconstriction and more long-lasting obstructive mechanisms (e.g. oedema), the acute increase in $R \mathrm{~L}$ was divided into $0-1 \mathrm{~h}$ and $1-4 \mathrm{~h}$ time periods.

Data are presented as mean \pm SEM. Statistical evaluations were performed using Quade test for nonparametric two-way analysis of variance and multiple comparisons on ranks of several related samples [16], Mann-Whitney U-test, Wilcoxon signed ranks test and Spearman's rank correlation test using a statistical package (Statistica, Statsoft) on an Apple Macintosh computer.

\section{Results}

\section{Plasma cortisol}

Plasma cortisol levels were $455 \pm 37(n=7)$ and $40.1 \pm 3.8$ $(\mathrm{n}=8)$ in sensitized, non-metyrapone treated and sensitized, metyrapone-treated animals, respectively, at the time of allergen challenge. In the nonsensitized, metyraponetreated pigs, the cortisol level was $33.3 \pm 2.3(n=5)$.

\section{Total lung resistance}

After challenge with $A$. suum aerosol, sensitized pigs developed an acute increase in $R \mathrm{~L}$ (fig. 1). The acute total increase (AUC) in $R_{\mathrm{L}}$ between $0-1 \mathrm{~h}$ was similar in the two sensitized groups $(23.1 \pm 10.3$ and $20.4 \pm 2.6$ $\% \cdot \mathrm{h}$ in non-metyrapone-treated and metyrapone-treated pigs, respectively). However, during the latter part of the acute reaction $(1-4 \mathrm{~h})$, there was a tendency towards an increased AUC in sensitized, metyrapone-treated pigs $(43.2 \pm 10.0 \% \cdot h)$ compared to that in sensitized, nonmetyrapone-treated animals $(13.1 \pm 29.8 \% \cdot h)(\mathrm{p}<0.10$, Mann-Whitney U-test). In sensitized, metyrapone-treated pigs, a late increase in $R_{\mathrm{L}}$ was also seen $(72.6 \pm 18.9 \% \cdot \mathrm{h})$, starting at about $4 \mathrm{~h}$, whereas no late response was seen in non-metyrapone-treated animals $(-4.4 \pm 25.3 \% \cdot \mathrm{h} ; \mathrm{p}<0.05$, Mann-Whitney U-test compared to sensitized, metyrapone-treated pigs). The non-sensitized, metyraponetreated pigs did not react when challenged with allergen.

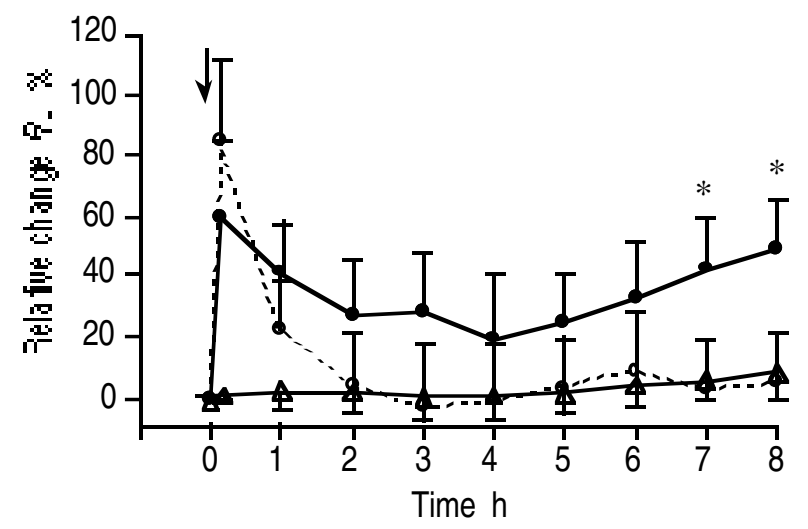

Fig. 1. - Relative change (\%) from baseline in total lung resistance $(R \mathrm{~L})$ after allergen challenge in sensitized, non-metyrapone-treated $(O)$, sensitized, metyrapone-treated $(\bullet)$ and nonsensitized, metyraponetreated pigs $(\Delta)$. Values are presented as mean and SEM $(n=5-8)$. *: $\mathrm{p}<0.05$, compared to sensitized, non-metyrapone-treated pigs (MannWhitney U-test). Arrow indicates allergen challenge.

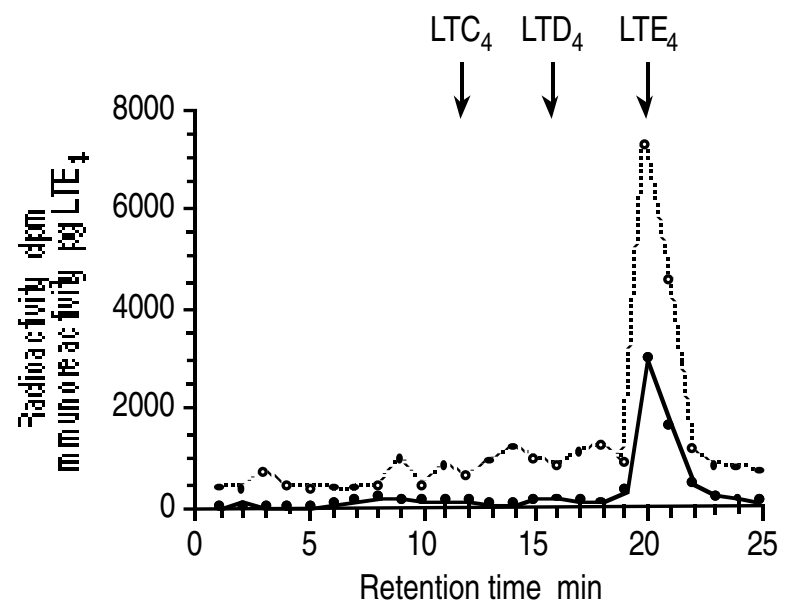

Fig. 2. - High performance liquid chromatography (HPLC) of pooled urine samples obtained during the acute reaction $(0-2 \mathrm{~h})$. Aliquots of HPLC-fractions were assayed for immunoreactive $\mathrm{LTE}_{4}$ with radioimmunoassay (O). Radioactivity measurements in a parallel sample indicate the retention time and recovery of ${ }^{3} \mathrm{H}-\mathrm{LTE}_{4}(\bullet)$. Retention times for $\mathrm{LTC}_{4}, \mathrm{LTD}_{4}$ and $\mathrm{LTE}_{4}$ are indicated with arrows. $\mathrm{LTC}_{4}$, $\mathrm{LTD}_{4}$ and $\mathrm{LTE}_{4}$ : leukotriene $\mathrm{C}_{4}, \mathrm{D}_{4}$ and $\mathrm{E}_{4}$. 


\section{Urinary methylhistamine and leukotriene $E_{4}$}

The specificity of the radio-immunoassay for $\mathrm{LTE}_{4}$ and the authenticity of the immunoreactive $\mathrm{LTE}_{4}$ measured in the urine samples are shown in fig. 2. The single immunoreactive peak corresponded to the retention time of synthetic tritiated as well as unlabelled $\mathrm{LTE}_{4}$. The loss of ${ }^{3} \mathrm{H}-\mathrm{LTE}_{4}$ during HPLC was $57 \%$, which was used as an index of $\mathrm{LTE}_{4}$ recovery. The amounts recovered in the HPLC-fractions correlated well with those measured in the crude urine samples.

When correlated to creatinine, the excretion of methylhistamine was constant during the observation period $(8 \mathrm{~h})$ in nonsensitized pigs, both in non-metyrapone-treated pigs (not shown) and in metyrapone-treated animals (fig. $3 \mathrm{c}$ ). The basal excretion of $\mathrm{LTE}_{4}$ in non-sensitized pigs steadily decreased both in non-metyrapone-treated pigs
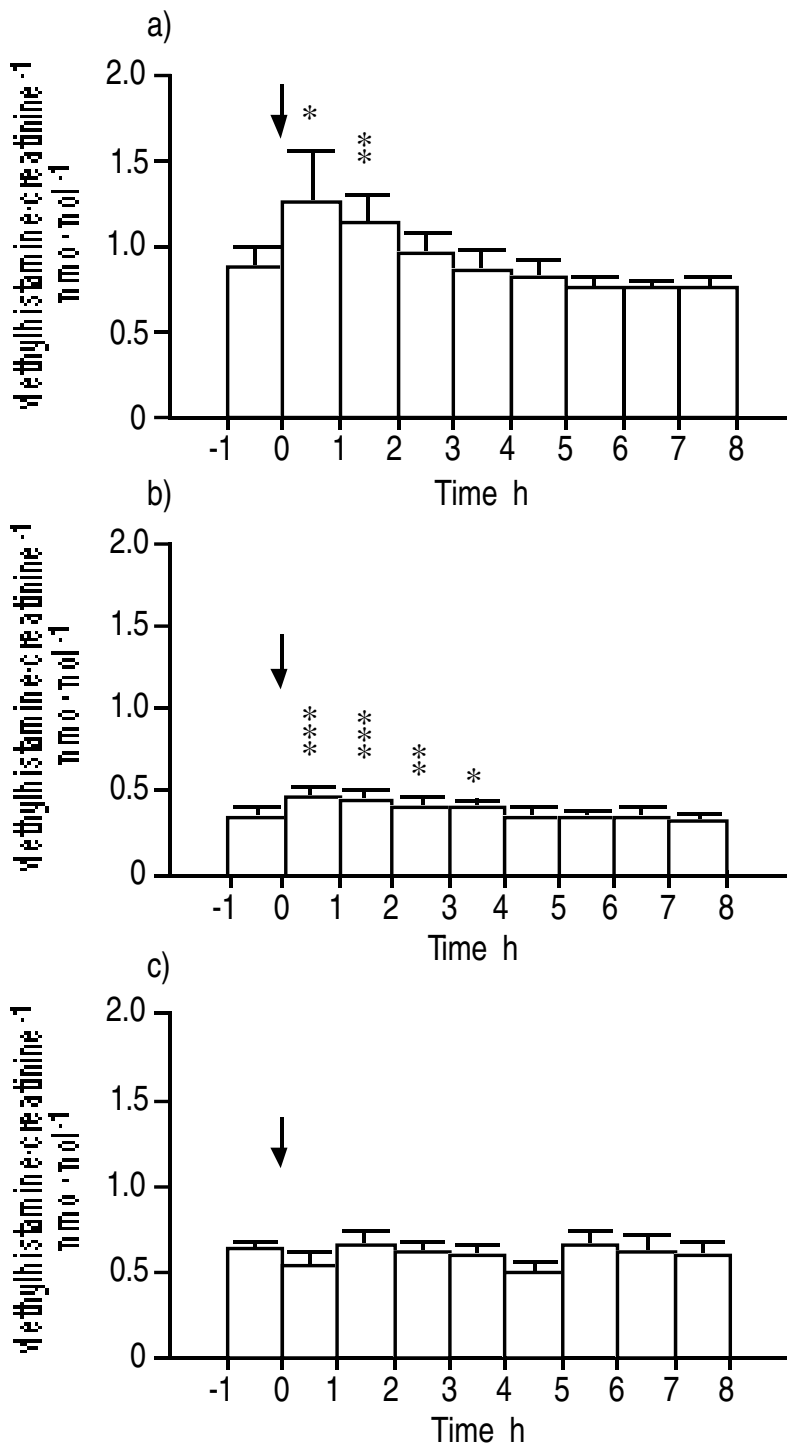

Fig. 3. - Urinary levels of methylhistamine in: a) sensitized, nonmetyrapone, b) sensitized, metyrapone-treated, and c) nonsensitized, metyrapone-treated pigs. The urine was collected in one hour fractions, from $1 \mathrm{~h}$ before until $8 \mathrm{~h}$ after allergen challenge. Values are presented as mean and SEM $(\mathrm{n}=5-8)$. *: $\mathrm{p}<0.05 ; * *$ : $\mathrm{p}<0.01$, ***: $\mathrm{p}<0.001$ compared to baseline (Quade test). Arrows indicate allergen challenge. (not shown) and in metyrapone-treated animals (fig. 4c), until reaching a steady-state at 5-6 h after the start of observation.

Lower basal levels of urinary methylhistamine were found in sensitized, metyrapone-treated animals than in all other groups $(\mathrm{p}<0.01$, Mann-Whitney U-test) (fig. $3 a-c)$. A tendency for higher basal levels of urinary $\mathrm{LTE}_{4}$ was noted in sensitized, metyrapone-treated pigs, compared to sensitized, non-metyrapone pigs $(\mathrm{p}<0.1$, Mann-Whitney U-test) (fig. 4a,b).

An increase in methylhistamine excretion was found in urine collected during the acute allergic response in both sensitized groups, with a maximum between $0-1 \mathrm{~h}$ after challenge (figs $3 a$ and $b$ ). No increase was seen between $4-8 \mathrm{~h}$, however.

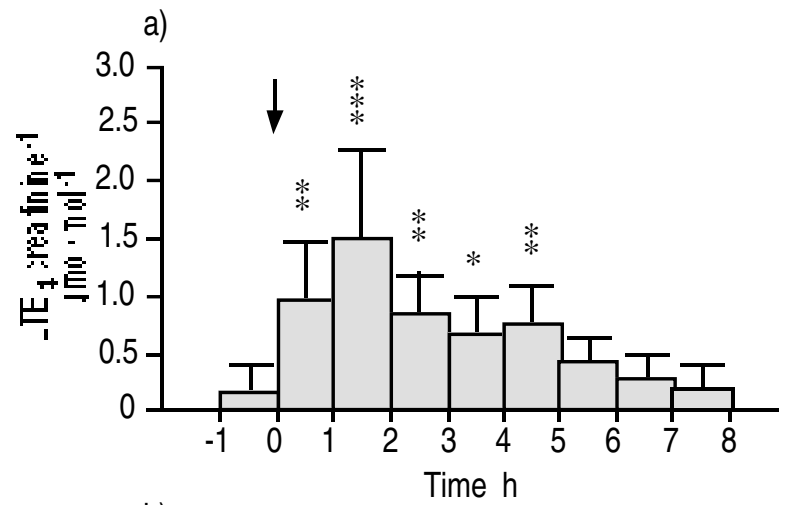

b)
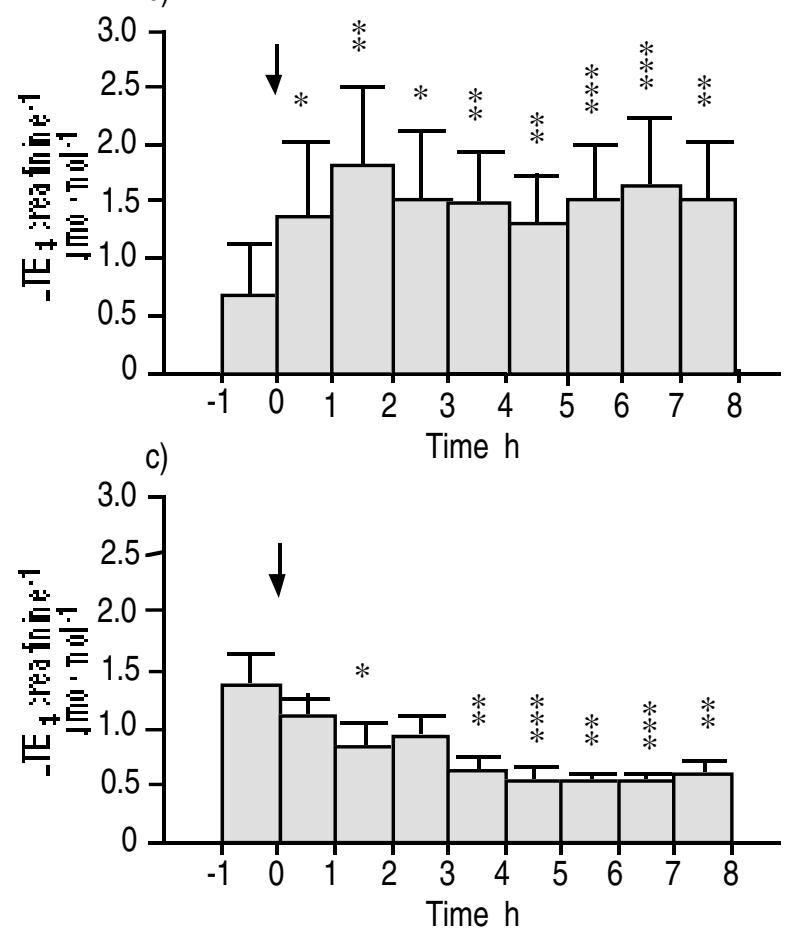

Fig. 4. - Urinary levels of $\mathrm{LTE}_{4}$ in: a) sensitized, non-metyrapone, b) sensitized, metyrapone-treated, and c) nonsensitized, metyrapone pigs. Note that the levels in both sensitized groups are expressed (to compensate for the decrease in $\mathrm{LTE}_{4}$ during the day) as the increase in $\mathrm{LTE}_{4}$ compared to nonsensitized, metyrapone pigs. The urine was collected in one hour fractions, from $1 \mathrm{~h}$ before until $8 \mathrm{~h}$ after allergen challenge. Values are presented as mean and SEM $(\mathrm{n}=5-8)$. * : $\mathrm{p}<0.05$, $* *: \mathrm{p}<0.01, * * *: \mathrm{p}<0.001$ compared to baseline (Quade test). Arrows indicate allergen challenge. 
Table 1. - AUC for total increases in urinary methylhistamine and $\mathrm{LTE}_{4}$ in sensitized pigs for different time periods after allergen challenge

\begin{tabular}{crc}
\hline & $\begin{array}{c}\text { Non-metyrapone } \\
\text { treated }\end{array}$ & $\begin{array}{c}\text { Metyrapone } \\
\text { treated }\end{array}$ \\
\hline $\begin{array}{c}\text { Methylhistamine } \mathrm{mmol} \cdot \mathrm{mol}^{-1} \cdot \mathrm{h} \\
0-2 \mathrm{~h}\end{array}$ & $0.64 \pm 0.34$ & $0.20 \pm 0.07$ \\
$2-5 \mathrm{~h}$ & $-0.01 \pm 0.26$ & $0.07 \pm 0.07$ \\
$5-8 \mathrm{~h}$ & $-0.13 \pm 0.34$ & $-0.01 \pm 0.09$ \\
$\mathrm{LTE}_{4} \mu \mathrm{m} \mathrm{mol} \cdot \mathrm{mol}^{-1} \cdot \mathrm{h}$ & & \\
$0-2 \mathrm{~h}$ & $1.8 \pm 0.9$ & $1.6 \pm 0.6$ \\
$2-5 \mathrm{~h}$ & $1.8 \pm 0.8$ & $1.6 \pm 1.0$ \\
$5-8 \mathrm{~h}$ & $0.1 \pm 0.6$ & $2.2 \pm 0.9^{*}$ \\
\hline
\end{tabular}

AUC: area under curve; $\mathrm{LTE}_{4}$ : leukotriene $\mathrm{E}_{4}$. *: $\mathrm{p}<0.05$ compared to non-metyrapone-treated pigs, Mann-Whitney U-test.

Table 2. - Morning (9 a.m.) basal counts of blood leucocytes 20 min after induction of anaesthesia $(n=14)$ and before administration of metyrapone

\begin{tabular}{ll}
\hline Cell type & $10^{9}$ cells $\cdot \mathrm{L}^{-1}$ \\
\hline Leucocytes & $11.0 \pm 1.29$ \\
Eosinophils & $0.06 \pm 0.01$ \\
Neutrophils & $2.60 \pm 0.37$ \\
Lymphocytes & $8.18 \pm 0.63$ \\
Monocytes & $0.20 \pm 0.02$ \\
Basophils & $0.04 \pm 0.02$ \\
\hline
\end{tabular}

All values are presented as mean \pm SEM. *: no differences were found between sensitized and nonsensitized pigs.

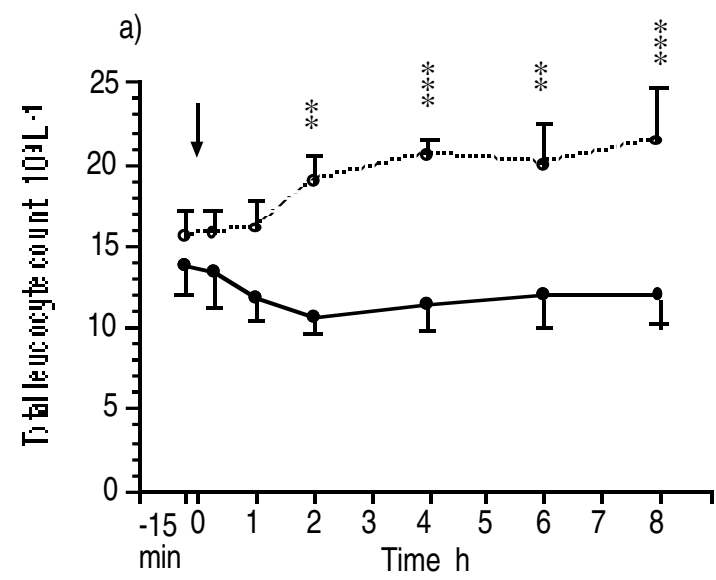

c)

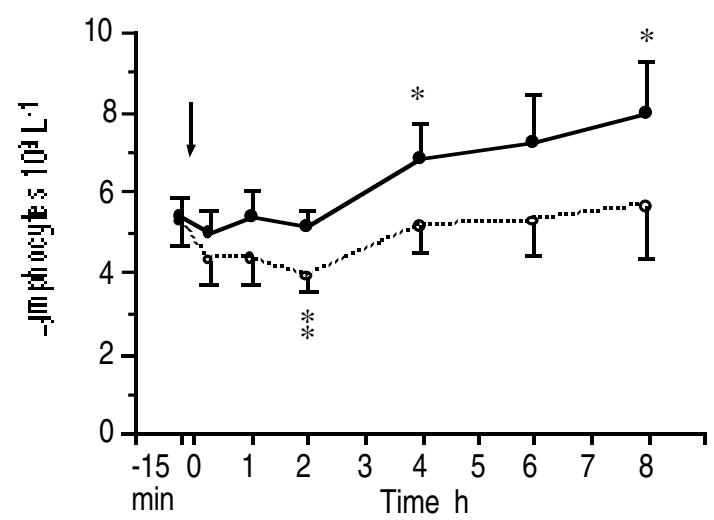

Compared to nonsensitized animals, there was an acute increase in urinary $\mathrm{LTE}_{4}$ levels in both sensitized groups, with a maximum between 1-2 $\mathrm{h}$ after allergen challenge (figs $4 \mathrm{a}$ and $\mathrm{b}$ ). In non-metyrapone-treated pigs the rate of excretion returned to baseline after about 5 $\mathrm{h}$, whilst in metyrapone-treated animals there seemed to be a continuous excretion during the observation period.

AUCs for total increases in excreted methylhistamine and $\mathrm{LTE}_{4}$ are presented in table 1 . The only statistical difference between the two sensitized groups was for $\mathrm{LTE}_{4}$ excretion during 5-8 $\mathrm{h}$ after allergen challenge.

\section{Blood leucocytes}

During the course of surgery, total leucocyte count increased from morning basal levels (table 2) by $34 \%$ in non-metyrapone-treated pigs $(\mathrm{p}<0.05$, Wilcoxon signed ranks test). At the same time, the number of neutrophils increased 3.7 times $(\mathrm{p}<0.001)$, whereas lymphocyte numbers decreased by $39 \%(p<0.01)$. Eosinophil, monocyte and basophil numbers did not change during this time in non-metyrapone-treated pigs.

At $8 \mathrm{~h}$ after allergen challenge, total leucocyte number had increased further in sensitized, non-metyraponetreated pigs (fig. 5a). However, total leucocyte numbers in sensitized, metyrapone-treated pigs did not change from morning basal levels during the experiment and this was also seen in nonsensitized, metyrapone-treated pigs.

b)

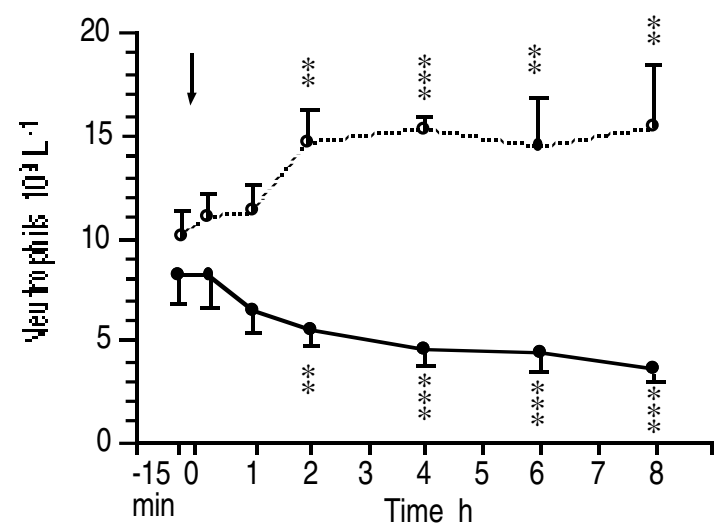

d)

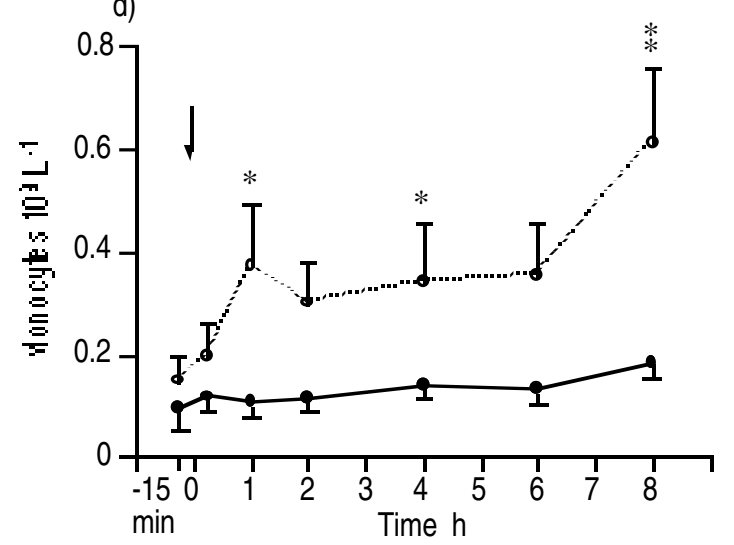

Fig. 5. - a) total leucocyte count; b) neutrophils; c) lymphocytes; and d) monocytes in arterial blood, 15 min before and during $8 \mathrm{~h}$ after allergen challenge in sensitized, non-metyrapone-treated $(O)$ and sensitized, metyrapone-treated pigs $(\bullet)$. Values are presented as mean and SEM $(\mathrm{n}=5-8)$. $*: \mathrm{p}<0.05 ; * *: \mathrm{p}<0.01 ; * * *: \mathrm{p}<0.001$, compared to baseline (Quade test). Arrows indicate allergen challenge. 
During the observation period $(-15 \mathrm{~min}$ to $8 \mathrm{~h}$ after allergen challenge), the number of neutrophils remained high in sensitized, non-metyrapone-treated pigs (fig. 5b). In contrast a consistent decrease was seen in sensitized, metyrapone-treated pigs. No difference between neutrophil numbers in sensitized and nonsensitized pigs could be seen. In two pigs, blood leucocytes were counted every 15 min after induction of anaesthesia. A biphasic increase in blood neutrophils was seen, with a maximum at about $45 \mathrm{~min}$, followed by a decrease to basal levels at about $90 \mathrm{~min}$. A second rise in blood neutrophils was then noted, reaching plateau levels at about 150-180 min after induction of anaesthesia (not shown).

The lymphocyte number in sensitized, non-metyraponetreated pigs (fig. 5c) showed a transient decrease, with a minimum at $2 \mathrm{~h}$ after allergen challenge, whereas in sensitized, metyrapone-treated pigs, lymphocyte numbers increased steadily during the observation period. Nonsensitized pigs showed the same pattern of changes in lymphocyte number as sensitized animals.

The monocyte number increased in sensitized, nonmetyrapone-treated pigs, with a maximum at $8 \mathrm{~h}$ (fig. 5d), but was constant and low throughout the experiment in sensitized, metyrapone-treated pigs. Similar changes were observed in nonsensitized pigs.

In sensitized, non-metyrapone-treated pigs, depletion

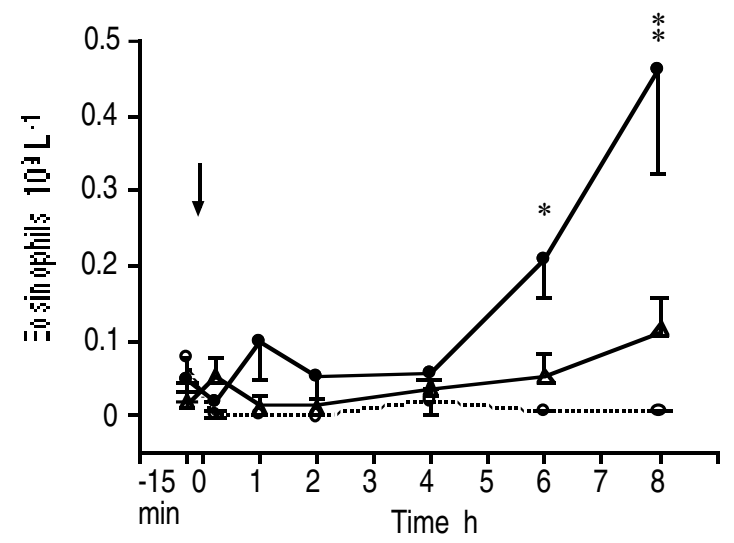

Fig. 6. - Eosinophil count in arterial blood, $15 \mathrm{~min}$ before and during $8 \mathrm{~h}$ after allergen challenge in sensitized, non-metyrapone-treated $(\mathrm{O})$, sensitized, metyrapone-treated $(\bullet)$ and nonsensitized, metyraponetreated pigs $(\Delta)$. Values are presented as mean and SEM $(\mathrm{n}=5-8)$. *: $\mathrm{p}<0.05 ; * *: \mathrm{p}<0.01$, compared to baseline (Quade test). Arrows indicate allergen challenge. of eosinophils from the blood was seen during the observation period (fig. 6). Pretreatment with metyrapone inhibited such depletion as seen in nonsensitized animals. In sensitized, metyrapone-treated pigs, an increase in blood eosinophil number could be seen at 5-6 h, and at $8 \mathrm{~h}$ after allergen challenge the increase had become tenfold. Furthermore, 15 min before allergen challenge, sensitized pigs tended to have higher numbers of blood eosinophils than nonsensitized pigs, irrespective of metyrapone treatment $(\mathrm{p}<0.10$, Mann-Whitney U-test).

Basophil numbers remained very low $\left(<0.08 \times 10^{9} \cdot \mathrm{L}^{-1}\right)$ in all pigs and did not seem to be affected by metyrapone treatment or allergen challenge, with the exception that mean basophil numbers were lower at all times in sensitized, metyrapone-treated pigs than in the other groups (not shown).

\section{Bronchoalveolar lavage cells}

The recovery of BAL fluid and total cells was lower in sensitized, metyrapone-treated pigs than in the other two groups (table 3 ). No significant differences in BAL cell differential count could be detected $8 \mathrm{~h}$ after allergen challenge in sensitized pigs compared to nonsensitized animals. However, there was a tendency towards higher lymphocyte numbers in sensitized, non-metyrapone-treated pigs than in the other groups.

When examined by light microscopy in Türk's solution in a Bürker chamber, aggregated (three or more cells) BAL macrophages were constantly found in high amounts in pigs receiving a late reaction, whilst aggregations were absent in non-late responders.

\section{Correlation between airways obstruction, mediator release and eosinophil count}

In sensitized, metyrapone-treated pigs, correlation analysis on total increases (AUC) in $R \mathrm{~L}$, mediator release and eosinophil numbers was performed. Correlation coefficients are given in table 4. Only AUCs with positive mean values were used. Excretion of methylhistamine, but not $\mathrm{LTE}_{4}$, tended to correlate with AUC for the acute bronchoconstriction ( $0-1 \mathrm{~h})$. Interestingly, AUC for the latter part of the acute increase in $R \mathrm{~L}(1-4 \mathrm{~h})$ showed a negative correlation with blood eosinophilia

Table 3. - Recovery of BAL fluid, total cell number, cell concentration and differential cell count of cells in BAL collected $8 \mathrm{~h}$ after allergen challenge $(n=4-8)$

\begin{tabular}{lccc}
\hline & $\begin{array}{c}\text { Sensitized, } \\
\text { non-metyrapone }\end{array}$ & $\begin{array}{c}\text { Sensitized, } \\
\text { metyrapone }\end{array}$ & $\begin{array}{c}\text { Nonsensitized } \\
\text { metyrapone }\end{array}$ \\
\hline Fluid recovery mL & $79 \pm 2$ & $57 \pm 5^{*}$ & $72 \pm 4$ \\
Total cells $10^{6}$ & $36 \pm 3$ & $18 \pm 3^{*}$ & $42 \pm 14$ \\
Cell conc. $10^{4} \cdot \mathrm{mL}^{-1}$ & $47 \pm 5$ & $31 \pm 6$ & $57 \pm 18$ \\
Macrophages \% & $91.3 \pm 1.7$ & $91.3 \pm 1.5$ & $92.0 \pm 1.2$ \\
Eosinophils \% & $0.1 \pm 0.1$ & $0.3 \pm 0.1$ & $0.0 \pm 0$ \\
Neutrophils \% & $3.9 \pm 1.8$ & $6.4 \pm 1.3$ & $5.9 \pm 1.6$ \\
Lymphocytes \% & $4.6 \pm 1.2^{\dagger}$ & $1.7 \pm 0.3$ & $1.9 \pm 0.5$ \\
\hline
\end{tabular}

All values are presented as mean \pm sEM. BAL: bronchoalveolar lavage. $\dagger: \mathrm{p}<0.1 ; *$ : $\mathrm{p}<0.05$, compared to the other two groups (Mann-Whitney U-test). 
Table 4. - Correlation coefficients $(r)$ in sensitized, metyrapone-treated pigs for comparisons between AUC for changes in $R$, excreted amount of methylhistamine and LTE $_{4}$, and blood eosinophils, at different time periods after allergen challenge using Spearman's rank correlation test

\begin{tabular}{lcccccc}
\hline & \multicolumn{2}{c}{ Methylhistamine } & \multicolumn{2}{c}{ LTE $_{4}$} & \multicolumn{2}{c}{ Eosinophils } \\
& $\mathrm{r}$ & time & $\mathrm{r}$ & time & \multicolumn{2}{c}{ time } \\
\hline$R \mathrm{~L} 0-1 \mathrm{~h}$ & $+0.62^{\dagger}$ & $0-2 \mathrm{~h}$ & +0.67 & $0-2 \mathrm{~h}$ & -0.14 & $4-8 \mathrm{~h}$ \\
$R \mathrm{~L} 1-4 \mathrm{~h}$ & +0.43 & $2-5 \mathrm{~h}$ & +0.01 & $2-5 \mathrm{~h}$ & $-0.83^{*}$ & $4-8 \mathrm{~h}$ \\
$R \mathrm{~L} 4-8 \mathrm{~h}$ & - & $5-8 \mathrm{~h}$ & +0.12 & $5-8 \mathrm{~h}$ & -0.31 & $4-8 \mathrm{~h}$ \\
\hline
\end{tabular}

AUC: area under curve; $R \mathrm{~L}$ : total lung resistance; $\mathrm{LTE}_{4}$ : leukotriene $\mathrm{E}_{4}{ }^{\dagger}{ }^{\dagger}: \mathrm{p}<0.1 ; *$ : $\mathrm{p}<0.05$.

(4-8 h). Blood eosinophilia did not correlate with urinary excretion of methylhistamine or $\mathrm{LTE}_{4}$ at any time period (not shown).

\section{Discussion}

Dual asthmatic responses to allergen challenge occur in some individuals, but the exact mechanisms for the development of late-phase reactions are not fully understood. Since the late asthmatic response is thought to reflect the inflammatory part of the reaction to allergen, we wanted to develop a novel animal model where mediator release, cellular events and various physiological parameters could be studied in an integrated way. We describe here late-phase reactions to allergen challenge in the lower airways in the actively-sensitized pig, regarding cellular movement and mediator release.

The normal range of plasma cortisol levels in conscious, unrestrained pigs has been shown to be $75-140 \mathrm{nM}$, which is far below the levels seen in pigs after surgical trauma [4]. One of the problems inherent when studying inflammatory events in an animal model is the fact that high cortisol levels could affect cytokine production and, consequently, influence the inflammatory response [17]. Since glucocorticoids very effectively inhibit the latephase reaction $[4,18]$, it may be important to routinely take into account endogenous cortisol levels in experimental animals, when studying inflammatory processes. Low cortisol levels were obtained by using the cortisolsynthesis inhibitor metyrapone [14].

It has been shown that infusion of cortisol in humans increases the half-life of circulating neutrophils, whilst infusion of another stress hormone, adrenaline, mobilizes the entire marginated pool of neutrophils [19]. This is consistent with the biphasic increase in circulating blood neutrophils seen in the present study after induction of anaesthesia and during the surgical preparation. Since a profound increase in plasma adrenaline was seen in conjunction with the induction of anaesthesia [4], it may be suggested that the rapid neutrophilia is dependent on adrenaline release, while the second increase is caused by the progressive increase in plasma cortisol levels [4]. The neutrophilia and the high plasma cortisol levels persisted in non-metyrapone-treated pigs, but in metyrapone-treated animals the blood neutrophil number decreased to normal levels [20] at $8 \mathrm{~h}$. The effect of high cortisol levels on blood eosinophils and lymphocytes seemed to be the reverse. A decrease in blood levels of both these cell types after administration of the synthetic glucocorticoid prednisone has also been shown in humans [21].

Eosinophils are highly sensitive to glucocorticoids: eosinophil chemotaxis, migration and adherence to endothelium are blocked, primarily because glucocorticoids decrease the expression of stimulating cytokines [13]. In this study, no blood eosinophils were detected at $8 \mathrm{~h}$ in pigs with high cortisol levels. However, in metyraponetreated, sensitized animals, blood eosinophil count had at $8 \mathrm{~h}$ after allergen challenge increased 10 times above baseline. This suggests recruitment from the bone marrow or increased survival of eosinophils in the circulation. In human asthmatics, a blood eosinopenia could be seen, with a minimum eosinophil count at about $4 \mathrm{~h}$ after allergen challenge [22]. After about $6-8 \mathrm{~h}$ the eosinophil count is back to basal levels, and at $24 \mathrm{~h}$ there is a prominent eosinophilia. Since the basal level of blood eosinophils in our sensitized pigs was low, no further decrease in eosinophils could be seen after the allergic reaction. However, the increase in eosinophil count starting at $4 \mathrm{~h}$ after allergen challenge seems to follow the same time course as in human asthmatics.

$\mathrm{LTC}_{4}$ and $\mathrm{LTD}_{4}$ induce a dose-dependent infiltration of eosinophils into the guinea-pig lung, which can be blocked by cys-LT-receptor antagonists [23]. LTD $_{4}$ induces both early- and late-phase allergen-induced bronchoconstriction in sheep of the dual-responder type [12], but this phenomenon was not found in humans [24]. However, $\mathrm{LTE}_{4}$ given to asthmatics elicits an increase in the numbers of eosinophils and neutrophils in the lamina propria of the airway mucosa $4 \mathrm{~h}$ after inhalation [11]. Since cys-LTs inhibit canine granulocyte migration [25], it is possible that the accumulation of granulocytes could be due to an increased retention of the cells rather than an active recruitment. Cys-LT-receptor antagonists given to allergic sheep [8] and humans [26] partially reverse the late response to allergen. However, in the pig no correlation between cys-LT release and blood eosinophil numbers or late airways obstruction was seen. Instead, since the latter part of the acute bronchoconstrictor response (1-4 h after allergen challenge) correlated negatively with the magnitude of the late-phase eosinophilia in pigs with low cortisol levels, the prolonged acute bronchoconstriction probably also involves increased release of eosinophil chemoattractants, possibly causing recruitment of eosinophils from the blood pool into lung tissue.

The importance of eosinophils in the late asthmatic 
bronchoconstrictor response has been debated. In humans, primarily eosinophil numbers [27], but also neutrophil numbers [28], are increased in BAL during the late-phase reaction. In dogs treated with metyrapone, primarily neutrophil accumulation was observed in BAL during the late-phase reaction [29], whereas in other animal models, an increase in eosinophils in BAL during the late-phase reaction has been described [30, 31]. In the present model, in which the lung has not been exposed to allergen prior to the acute provocation, $8 \mathrm{~h}$ seems to be too short a time period for the detection of increased levels of BAL eosinophils. In human chronic asthmatics as well as in naturally sensitized, repeatedly challenged sheep and actively-sensitized guinea-pigs [30, 31], the basal levels of eosinophils in bronchial tissue and blood before provocation are probably higher than in the sensitized pig [32], indicating preactivation of this cell population. Preactivated eosinophils in the blood may more readily infiltrate the lung, and cells already present in the lung may more rapidly migrate through the epithelium, yielding higher eosinophil numbers in BAL at $8 \mathrm{~h}$ after allergen challenge. The advantage of this model using actively-sensitized pigs, which have never previously been exposed to the relevant allergen in the lower airways and, consequently, have very low lung tissue eosinophil numbers, may be in studies of the onset of inflammatory reactions. However, we could not exclude a slight preactivation of eosinophils in sensitized pigs, since the prechallenge levels of blood eosinophils tended to be increased in sensitized compared to nonsensitized animals.

Airway mast cells are activated by allergen challenge in sensitized subjects and will release a battery of bronchoconstrictive mediators, such as histamine, cys-LTs and prostaglandin $\mathrm{D}_{2}$, all of which can be found in BAL fluid acutely after allergen challenge [33]. Histamine has been shown to be responsible for a large part of the acute bronchoconstrictor response to allergen in humans [34] and in the pig [35]. Histamine detected in plasma may represent not only mast cell-derived histamine, but also contaminating histamine from blood basophils released during sample handling. Therefore, in the present study we measured methylhistamine, one of the urinary metabolites of histamine [36]. This also enables direct and time-resolved comparison with the release of cysLTs, measured as $\mathrm{LTE}_{4}$ in urine. Pig plasma histamine levels are about 100 times higher than those of man [37], resulting also in higher basal levels of methylhistamine in urine. Surgical trauma may induce histamine release, but in the pig, plasma histamine levels have been shown to return to baseline $30 \mathrm{~min}$ after surgical manipulation [38]. Furthermore, methylhistamine levels in urine were stable in control pigs during the observation period in this study and increased rapidly after allergen challenge in sensitized animals, indicating rapid clearance of plasma methylhistamine to the urine.

Lower basal levels of urinary methylhistamine and lower blood basophil numbers were found in sensitized, metyrapone-treated pigs, indicating that a large part of basal free plasma histamine, which will influence urinary methylhistamine levels, is derived from circulating basophils. Since this group of sensitized pigs also showed slightly elevated prechallenge levels of circulating eosinophils, it may be suggested that low cortisol levels favour eosinophil differentiation or survival over that of basophils in sensitized animals. Increased numbers of eosinophils may also explain elevated basal urinary LTE $_{4}$ in this group. No sign of histamine release could be found during the late reaction in the pig, suggesting that reactivation of mast cells or basophil infiltration may not be involved in the late-phase bronchoconstrictor events, whereas the correlations made between AUC for $R \mathrm{~L}$ and mediators in the urine suggested that histamine is responsible for at least the first part of the acute bronchoconstriction.

The cys-LTs can be synthesized in large amounts from arachidonic acid, primarily in mast cells, basophils and eosinophils. Cys-LTs are potent bronchoconstrictors in humans [39], and can increase mucus release from human airways in vitro [40], and induce microvascular leakage in the airways [41], all events characteristic of the late-phase reaction. Elevated levels of $\mathrm{LTC}_{4}$ have been detected in human BAL fluid collected during the late-phase asthmatic reaction [28]. Measurements of the urinary metabolite $\mathrm{LTE}_{4}$ have been performed after allergen challenge in humans, and an acute increase in $\mathrm{LTE}_{4}$ has been shown [7]. However, a clear-cut late increase in urinary $\mathrm{LTE}_{4}$ has not yet been shown in humans [42]. In animal models, on the other hand, where acute responses of higher magnitude can be elicited, a continuous release of cys-LTs may be detected ([43] and present results).

HPLC characterization of cys-LTs in pig urine was performed in this study and the pattern was found to be similar to that in human urine [44], with $\mathrm{LTE}_{4}$ as the only urinary cys-LT. However, the levels of $\mathrm{LTE}_{4}$ were found to be approximately 10 times higher than in human urine. There was a continuous decrease in urinary $\mathrm{LTE}_{4}$ for $5 \mathrm{~h}$ after surgery (about $4 \mathrm{~h}$ after allergen challenge) in nonsensitized animals, both with and without metyrapone treatment. It may be suggested that an initial increase in the release of cys-LTs was induced by surgery, but we cannot exclude a circadian variation in cys-LT production in the pig. Consequently, we have calculated our data as increased amount of cys-LTs compared to that in control animals. In pigs with a late-phase reaction, but not in the other groups, a continuous release of cysLTs was seen, and it would be reasonable to suggest that at least some part of the late-phase airways obstruction is mediated by cys-LTs by bronchial and/or vascular effects, although no correlation between these components was found in the present study.

In conclusion, we have described a novel animal model in the pig in which the initiation of allergic inflammation in the lower airways can be studied. Metyrapone treatment, reducing cortisol levels to be more physiologically relevant, seems favourable to keep blood leucocyte numbers within the normal range, and a prominent blood eosinophilia was seen during the late-phase reaction in metyraponetreated animals. Furthermore, we found that cys-LTs are released in the late-phase as well as acute bronchoconstrictor response, but that histamine is released in the 
acute response only. The relationship between late-phase cys-LT release, eosinophilia and airways obstruction deserves further study.

Acknowledgements: The authors thank M. Stensdotter and C. Nihlén for expert technical and laboratory assistance.

\section{References}

1. Ellis AG. The pathological anatomy of bronchial asthma. Am J Med Sci 1908; 136: 407-429.

2. Alving K. Airways vasodilatation in the immediate allergic reaction: involvement of inflammatory mediators and sensory nerves. Acta Physiol Scand 1991; 141 (Suppl. 597): 1-64.

3. Alving K, Matran R, Fornhem C, et al. Late-phase bronchial and vascular responses to allergen in activelysensitized pigs. Acta Physiol Scand 1991; 143: 137138.

4. Fornhem C, Lundberg JM, Alving K. Allergen-induced late-phase airways obstruction in the pig: the role of endogenous cortisol. Eur Respir J 1995; 8: 928-937.

5. Church MK, Caulfield JP. Mast cell and basophil function. In: Holgate ST, Church MT, eds. Allergy. London, Gower Medical Publishing, 1993; pp. 5.1-5.12.

6. Keyzer JJ, Kauffman HF, de Monchy JGR, et al. Urinary $\mathrm{N} \tau$-methylhistamine during early and late allergen-induced bronchial-obstructive reactions. J Allergy Clin Immunol 1974; 74: 240-245.

7. Taylor GW, Taylor I, Black P, et al. Urinary leukotriene $\mathrm{E}_{4}$ after antigen challenge and in acute asthma and allergic rhinitis. Lancet 1989; i: 584-588.

8. Tagari P, Abraham WM, McGolrick J, et al. Increased leukotriene $\mathrm{E}_{4}$ excretion during antigen-induced bronchoconstriction in allergic sheep. J Appl Physiol 1990; 68: 1321-1327.

9. Sladek K, Dworski R, Fitzgerald GA, et al. Allergenstimulated release of thromboxane $\mathrm{A}_{2}$ and leukotriene $\mathrm{E}_{4}$ in humans. Am Rev Respir Dis 1990; 141: 1441-1445.

10. Shaw RJ, Cromwell O, Kay AB. Preferential generation of leukotriene $\mathrm{C}_{4}$ by human eosinophils. Clin Exp Immunol 1984; 56: 716-722.

11. Laitinen LA, Laitinen A, Haahtela T, et al. Leukotriene $\mathrm{E}_{4}$ and granulocytic infiltration into asthmatic airways. Lancet 1993; 341: 989-990.

12. Abraham WM, Russi E, Wanner A, et al. Production of early and late pulmonary responses with inhaled leukotriene $\mathrm{D}_{4}$ in allergic sheep. Prostaglandins 1985; 29: 715-726.

13. Altman LC, Hill JS, Hairfield WM. Effects of corticosteroids on eosinophil chemotaxis and adherence. J Clin Invest 1981; 647: 28-36.

14. Chart JJ, Sheppard HJ. Pharmacology and biochemistry of some amphenone analogues and other adrenal cortical inhibitors. J Med Pharm Chem 1959; 1: 407-441.

15. Dahlén B, Kumlin M, Margolskee DJ, et al. The leukotriene-receptor antagonist MK-0679 blocks airway obstruction induced by bronchial provocation with lysineaspirin in aspirin-sensitive asthmatics. Eur Respir J 1993; 6: $1018-1026$

16. Theodorsson-Norheim E. Friedman and Quade test: basic computer program to perform nonparametric two-way analysis of variance and multiple comparisons on ranks of several related samples. Comput Biol Med 1987; 17: 85-99.
17. Schleimer RP. Effects of glucocorticosteroids on inflammatory cells relevant to their therapeutic applications in asthma. Am Rev Respir Dis 1990; 141: S59S69.

18. Booij-Noord H, Orie NGM, de Vries K. Immediate and late obstructive reactions to inhalation of house dust and protective effects of disodium cromoglycate and prednisolone. J Allergy Clin Immunol 1971; 48: 344-354.

19. Davis JM, Albert JD, Tracy KJ, et al. Increased neutrophil mobilization and decreased chemotaxis during cortisol and epinephrine infusions. J Trauma 1991; 31: 725731.

20. Schmidt DA, Tumbleson ME. Swine hematology. In: Tumbleson ME, ed. Swine in Biomedical Research. Vol. 1-3. New York, Plenum Press, 1986; pp. 767-782.

21. Saavedra-Delgado AMP, Mathews KP, Pan PM, et al. Dose-response studies of the suppression of whole blood histamine and basophil counts by prednisone. J Allergy Clin Immunol 1980; 66: 464-471.

22. Dahl R, Venge P, Olsson I. Variations of blood eosinophils and eosinophil cationic protein in serum in patients with bronchial asthma: studies during inhalation challenge test. Allergy 1978; 33: 211-215.

23. Foster A, Chan CC. Peptide leukotriene involvement in pulmonary eosinophil migration upon antigen challenge in the actively sensitized guinea-pig. Int Arch Allergy Appl Immunol 1991; 96: 279-284.

24. Smith LJ, Greenberger PA, Patterson R, et al. The effects of inhaled leukotriene $\mathrm{D}_{4}$ in humans. Am Rev Respir Dis 1985; 131: 368-372.

25. Thomsen MK, Ahnfelt-Rønne I. Inhibition by the $\mathrm{LTD}_{4}$ antagonist, SR2640, of effect of $\mathrm{LTD}_{4}$ on canine polymorphonuclear leukocyte function. Biochem Pharmacol 1989; 38: 2291-2295.

26. Rasmussen JB, Eriksson L-O, Margolskee DJ, et al. Leukotriene $\mathrm{D}_{4}$ receptor blockade inhibits the immediate and late bronchoconstrictor responses to inhaled antigen in patients with asthma. J Allergy Clin Immunol 1992; 90: 193-201.

27. de Monchy JGR, Kauffman HF, Venge P, et al. Bronchoalveolar eosinophilia during allergen-induced late asthmatic reactions. Am Rev Respir Dis 1985; 131: 373-376.

28. Diaz P, Gonzalez MC, Galleguillos FR, et al. Leukocytes and mediators in bronchoalveolar lavage during allergeninduced late-phase asthmatic reactions. Am Rev Respir Dis 1989; 139: 1383-1389.

29. Sasaki H, Yanai M, Shimura S, et al. Late asthmatic response to Ascaris antigen challenge in dogs treated with metyrapone. Am Rev Respir Dis 1987; 136: 14591465.

30. Abraham WM, Sielczak MW, Wanner A. Cellular markers of inflammation in the airways of allergic sheep with and without allergen-induced late responses. Am Rev Respir Dis 1988; 138: 1565-1571.

31. Iijima H, Ishii M, Yamauchi $\mathrm{K}$, et al. Bronchoalveolar lavage and histologic characterization of late asthmatic response in guinea-pigs. Am Rev Respir Dis 1987; 136: 922-929.

32. Alving K, Sundström C, Matran R, et al. Association between histamine-containing mast cells and sensory nerves in the skin and airways of control and capsaicintreated pigs. Cell Tissue Res 1991; 264: 529-538.

33. Miadonna A, Tedeschi A, Brasca C, et al. Mediator release after endobronchial antigen challenge in patients with respiratory allergy. J Allergy Clin Immunol 1990; 85: 906-913. 
34. Curzen N, Rafferty P, Holgate ST. Effects of a cyclooxygenase inhibitor, flurbiprofen, and an $\mathrm{H}_{1}$ histamine receptor antagonist, terfenadine, alone and in combination on allergen induced immediate bronchoconstriction in man. Thorax 1987; 42: 946-952.

35. Alving K, Matran R, Lundberg JM. Capsaicin-induced local effector responses, autonomic reflexes and sensory neuropeptide depletion in the pig. Naunyn-Schmiedeberg's Arch Pharmacol 1991; 343: 37-45.

36. Eliassen KA. Metabolism of ${ }^{14} \mathrm{C}$-histamine in domestic animals. III. Horse and pig. Acta Physiol Scand 1971; 81: 300-306.

37. Lorenz W, Barth H, Kusche J, et al. Histamine in the pig: determination, distribution, release and pharmacological actions. Eur J Pharmacol 1971; 14: 155-175.

38. Lorenz W, Seidel W, Doenicke A, et al. Elevated plasma histamine concentration in surgery: causes and clinical significance. Klin Wochenschr 1974; 52: 419-425.

39. Barnes NC, Piper PJ, Costello JF. Comparative effects of inhaled leukotriene $\mathrm{C}_{4}$, leukotriene $\mathrm{D}_{4}$, and histamine in normal human subjects. Thorax 1984; 39: 500-504.
40. Marom Z, Shelhamer JH, Bach MK, et al. Slow-reacting substances $\mathrm{LTC}_{4}$ and $\mathrm{D}_{4}$ increase the release of mucus from human airways in vitro. Am Rev Respir Dis 1982; 126: 449-451.

41. Woodward DF, Weichman BM, Gil CA, et al. The effect of synthetic leukotrienes on tracheal microvascular permeability. Prostaglandins 1983; 25: 131-142.

42. Manning PJ, Rokach J, Malo J-L, et al. Urinary leukotriene $\mathrm{E}_{4}$ levels during early and late asthmatic responses. $J$ Allergy Clin Immunol 1990; 86: 211-220.

43. Brideau C, Chan C, Charleson S, et al. Pharmacology of MK-0591 (3-[1-(4-chlorobenzyl)-3-(t-butylthio)-5(quinolin-2-yl-methoxy)-indol-2-yl]-2,2-dimethyl propanoic acid), a potent, orally active leukotriene biosynthesis inhibitor. Can J Physiol Pharmacol 1992; 70: 799_ 807.

44. Kumlin M, Dahlén B, Björck T, et al. Urinary excretion of leukotriene $\mathrm{E}_{4}$ and 11-dehydro-thromboxane $\mathrm{B}_{2}$ in response to bronchial provocations with allergen, aspirin, leukotriene $\mathrm{D}_{4}$, and histamine in asthmatics. Am Rev Respir Dis 1992; 146: 96-103. 